\title{
Scenario Forecasting of Agriculture Institutional Transformation on Sustainable Development Base
}

\author{
YURII LOPATYNSKYI ${ }^{1}$, ZORIANA KOBELIA $^{2}$, LIUBOV VODIANKA $^{3}$, \\ IRYNA ANTOKHOVA ${ }^{4}$, ANDZHEI HALYTSKYI ${ }^{5}$ \\ 1,2,3,4,5 Department of Business and Human Resource Management, Yuriy Fedkovych Chernivtsi \\ National University, Chernivtsi, UKRAINE
}

\begin{abstract}
The aim of the study is to outline the scenarios of further institutional transformation of the Ukrainian agricultural sector based on concept of sustainable development. The basic stages of institutional transformation of the agricultural sector of Ukraine are considered in the article. The agricultural sector holds a significant place in the national economy of Ukraine in terms of share in GDP, percentage of employment, share in exports, etc. However, this does not contribute to the harmonious development of the agricultural sector of Ukraine and requires the introduction of a triple balanced development of the economic, ecological and social component, characterized by the concept of sustainable development. The authors propose to add an institutional component to these three elements. The institutional transformation of the Ukrainian agricultural sector is divided into five stages. Three scenarios of the forecast development of agricultural sector of Ukraine economy (pessimistic, realistic, and optimistic) are outlined in the article. The further perspectives concerning the national agricultural sector in the introduction of the concept of sustainable development are suggested.
\end{abstract}

Key-Words: - Agricultural sector, Institutional transformation, Forecast, Scenarios, Sustainable development, COVID-19.

Received: January 4, 2021. Revised: May 12, 2021. Accepted: May 25, 2021. Published: May 31, 2021.

\section{Introduction}

The transformation process of Ukrainian agricultural sector had a long and controversial character. Transition from the collective farm structure to market economic system was fundamental. Reforming agriculture policy was based on the liberalization of economic activities. Theoretical principles and agricultural transformation practice were inadequate to its objective attributes and institutional characteristics of the subjects of reform (agricultural producers). Economic realities demonstrate: the problematic of neoliberal concepts applying in transitive society at the initial stage of reforms, the lack of complex of necessary prerequisites for their implementation, the inertia of economic actors, and the uncertainty of the social base of structural transformation. The process of transforming the national economic system is an objective proof of theoretical and practical justification necessity of reforms. This justification is based on a multidisciplinary approach of various social sciences. In general the following requirements can be met by the Institutional Economics. Institutional and system approaches provide an opportunity to assess the overall progress and impact of agrarian transformation as well as determine its prospects.

Although Ukrainian modern agriculture shows growth, its actual state is worse than potential. The present resource base (as a real basis for economic and social growth) is mostly scattered and destroyed, the relationships with counterparty sectors are complicated. The agrarian market system needs improvement. Its imperfection is holding back the prospect of improving product quality in line with world standards. This should serve as a means of enhancing the competitiveness of producers, which is especially important due to the significant influence of globalization.

The debate concerning the assessment of reforms effectiveness and competitive strategy of agricultural sector development is still actual. Solving the theoretical and applied tasks of this research revealed the main problems and contradictions of agrarian reforms. This contributed to the elaboration of conceptual elements of further institutional transformations in the agricultural sector in the following areas: tactics of diversified development, formation of growth points and strategies for becoming an effective economy of the agricultural sector. 
The authors of the research see the future perspectives for the agricultural sector of Ukraine in the implementation of the concept of sustainable development.

The aim of the study is to outline the scenarios of further institutional transformation of the Ukrainian agricultural sector based on concept of sustainable development.

\section{Methodological Approach}

The genesis of world civilization is accompanied by constant changes of social order. These changes are characterized by the improvement of the socioeconomic structure, general civilization progress, increased interdependence and unification of economic system of individual countries. In figurative statement of Joseph Alois Schumpeter, the transformation of the social order is a continuous process [1]. This wave of reformation has also touched Ukraine, which together with the independence has chosen the path towards the transformation of society on market principles. This also applies to the agricultural sector.

The specific character of agriculture lies in its multi-functionality. This defines the role of the agriculture in the national economy sectors pyramid as a factor of food security, on the one hand, and sources of income, employment areas and farmers living environment, on the other. Modern agriculture is also the production base, the social environment, the bearer of cultural and historical heritage of the people. It performs ecological and recreational, space-communication and other functions.

The multi-functionality of agriculture and the course of reforming the Ukrainian agricultural system objectively confirm the rationale for further transformation of the agricultural sector on the basis of interdisciplinary approaches in the context of the theory of institutionalism. As we know, institutional theory combines economic, sociological and psychological approaches. On the other hand, the practice of agrarian reform proves the importance of creating favorable conditions for development of agricultural sector. Among these conditions, the priority belongs to the institutional components, since the direction of change is determined by the trajectory of previous development ("path dependence" according to Douglass Cecil North's [2] interpretation).

General provisions of the theory of institutionalism and its components are elaborated in social and economic sciences. The development of institutional theory is associated with the names of Thorstein Bunde Veblen (socio-psychological direction), Ronald Harry Coase, Oliver Eaton Williamson, Geoffrey Martin Hodgson (theory of transaction costs, property rights, etc.), Douglass Cecil North (economics history), James McGill Buchanan and Mançur Lloyd Olson (public choice theory), Armen Albert Alchian, Harold Demsetz, Svetozar Pejovich (theory of property rights), Frank Hyneman Knight, Claude Ménard (economic organizations), Laurent Thévenot, Olivier Favereau (economic arrangements), Herbert Alexander Simon (theory of bounded rationality), Gary Stanley Becker, Thrainn Eggertsson (theory of economic behavior), Richard R. Nelson, Sidney Graham Winter (evolutionism) and many others.

It should be noted that some scientists of the institutional direction of economic thought simultaneously represent different branches of institutionalism. This defines the versatility of institutionalism as a social science.

A lot of studies are also devoted to the consideration of the general concept of sustainable development, as well as its application in the agricultural sector (e.g. [3-5] and many others).

It is worth noting the study of the features of small scale farmers [6] and household ones [7].

There are numerous studies concerning the agricultural sector of Ukraine (Borodina O. et al. [8]; Zinchuk et al. [9]; Shpykuliak et al. [10]; Onegina et al. [11] etc.).

The institutional approaches are also actively developing in Ukraine, which is confirmed by many publications on this subject. However, the practical application of institutional theory to specific sectors of the economy is presented poorly. This is especially true of the agricultural sector of the economy and its institutional transformation process.

Thus, the theory of institutionalism and the concept of sustainable development are quite detailed and developed. The motivation behind this work and the contributions of this work with respect to previous works in literature is to apply these theory and concept to the analysis of phasing transformation of the agricultural sector of Ukraine and scenario forecasting of its development.

The following methods were used in the study: induction, logic, observation, analysis, formulating hypotheses, deductive reasoning and deriving predictions, expert assessments and scenario method. It is also worth mentioning the multidisciplinary agroecosystem analysis. The theoretical bases of the study were systems theory, theory of institutionalism, the concept of sustainable development. 


\section{Result and Discussion}

\subsection{Phasing Transformation of the Agricultural Sector of Ukraine}

One of the goals of market transformation is to establish market institutions, which collectively form the institutional matrix of agrarian system. However, production of new market institutions comes into conflict with existing old economic mechanisms and the inertia of informal institutions of economic entities behavior. Therefore, the process of introducing an institutional matrix of the market model at the initial stage was rather a change of form than the essence of the functioning of the national economy. This is hampered by the lack of a market economic environment, market thinking, etc.

The priority of agricultural institutions development can be represented as the dominant vector of transformation in the system of market coordinates. Accordingly, on the basis of systematic approach the following large-scale stages of institutional transformation of the agricultural sector of modern Ukraine can be identified.

The first stage - from 1991 to 1999 inclusively is characterized by the changes and reorganization, served as some fluctuations of system. The old economic system is essentially unchanged, not falling into chaos, but not moving to a higher level. The chaotization as well as the entropy of the system and the number of possible options for its behavior increase in a transition economy. Thus, the role of management, regulation and coordination is enhanced. At this time the drastic reduction of public administration was considered inappropriate. A characteristic feature of the first stage is the fact that the old mechanisms do not operate any longer, and new ones have not yet been formed. The dynamic agricultural sector is at the bifurcation point (in physical terminology), acquiring a new quality in its movement by changing its parameters.

The second stage of agrarian transformation in Ukraine started in 2000 and can be defined as postbifurcation period. It is characterized by rapid reform based on private property and can be regarded as a phase transition of the agrarian system to a new quality level. The role of external factors is clearly demonstrated. Thus, the initiation of organizational and structural changes, the choice of economic forms, etc. took place on the recommendations of the government. This stage is characterized by formal completion of the restructuring of collective farms and the transition to the final stage of privatization of agricultural land. The peculiarity of this period is also the fact that the initiative of reform is gradually shifted from the state to agribusiness. Of course, the benefits of private ownership are indisputable. Therefore, it acts as an attractor of transformation and dominates the economic interests of economic entities. In general, this condition can be considered as a starting point for further transformation processes, because the diversity of legal economic forms provides flexibility of the agrarian system.

At the same time, a third stage is emerging within the existing agrarian sphere - a post-reform transformation. It can be characterized by metamorphoses of "new" economic entities created in the 2000 reform process. In fact changing of the status, legal forms and sizes of newly formed facilities is taking place. This process is influenced by two factors: internal and external in relation to the agrarian system. Internal is based on choice and selection, the processes of adaptation of economic entities, etc. External factors include the mechanism of interaction with the sector counterparties, the system of preferences, privileges to certain forms of business, in particular in taxation, etc. These factors can also be considered as attractors. Attractor competition can be an example of the multidirectional action of current and perspective interests. It should be noted that, according to the synergistic concept, the choice under the influence of an external attractor is temporary and insufficient (which, of course, does not mean neglect of the question of its validity). In this case, the impact of the external attractor can not only cause movement in one plane (e.g., from one economic form to another), but the transition to another plane (for example, the formation of vertically integrated formations, agro-industrial-financial groups, agricultural holdings, etc.).

The timeframes of the boundaries of the second and third stages are not clearly defined. As one of the possible criterion of separating this stage we suggest Ukraine's accession to the WTO in 2008. This period is characterized by an active increase in the number of large-scale corporate structures (agricultural holdings).

It can be stated that 2014 starts the fourth stage of the national agricultural sector transformation, connected with the Ukraine's signing of the Ukraine-European Union Association Agreement and the relevant changes in the direction of harmonization with the European Agricultural principles. This imposes specific obligations on compliance with sustainability requirements in agrarian development.

It was after Ukraine signed an Association Agreement with the EU the need to overcome the 
existing problems of agricultural sector of Ukraine became actualized. This makes it urgent to determine the priorities and guidelines of the sector's development based on the concept of sustainability. Instead, Ukraine is characterized by low activity in the transition from theory to sustainable development practice, in particular - in the agricultural sector of the national economy.

In general, the state of development of the modern agricultural sector of Ukraine is characterized by the following components:

- The economic parameters of development of agricultural sector of Ukraine overwhelmingly represented a U-shaped trend of decline in the early 1990s and the growth after 2000 (this is shown in Figure 1). Despite the growth, the economic efficiency of the sector remains low, while differing for households, farms, small and medium-sized enterprises, on the one hand, and the holdings on the other.

- Ukrainian agricultural sector is characterized by a significant share of GDP and high rates of employment compared with developed countries. This defines its role in the sustainable economic development of Ukraine as a whole.

- There is a duality of modern agricultural systems of Ukraine, represented mainly by small agricultural producers and large agricultural enterprises (holdings).

Ecological imperatives (mandatory for consideration) are influenced by global warming factors, as well as a high level of environmental pollution in Ukraine, tilled soil and deterioration of their quality, the dominance of monocultures, industrial plants, etc. This leads to the formulation of further tasks of sustainable development of Ukrainian agricultural sector. These tasks foremost concern agricultural enterprises as a main system component.

- Agricultural holdings usually use modern technologies of agricultural production but they are not motivated to introduce environmentally friendly ones. In contrast, in households and small-scale agricultural enterprises, the lack of funds causes, first of all, the low level of chemicalisation of agricultural production. However, in general, the agricultural sector of Ukraine, due to various factors, causes a fairly high level of pollution.

- In the structure of agricultural production a significant proportion of crops that consume the land, is not used for food production. The imbalance is also determined by a low proportion of livestock.

- Social determinants of sustainable development of the agricultural sector of national economy are characterized by low levels of social, labor, and life conditions, insufficient wages and social security workers and poor social infrastructure in rural areas. This does not contribute to the development of human capital in these areas. As a result, most of rural residents are not engaged in agricultural production but work in the cities and abroad.

Taken together, these components do not contribute to the sustainable development of the national agricultural sector.

In our opinion, the fifth stage of agricultural transformation begins in 2020. This is due to the legislative regulation of the conditions of circulation (sale) of agricultural land. That means the lifting of a long-term moratorium on land sales which should help to complete the full formation of a bundle of property rights.

Another factor that will affect not only the agricultural sector of Ukraine, but also the world economy in general, is the Coronavirus COVID-19 Pandemic. This impact is so significant that it marks the beginning of a new stage of world development. Many studies have been devoted to this issue [1215], so in ours we do not dwell on this in detail.

These factors have different focus and duration. The coronavirus crisis is a short-term destimulator factor that discourages economic development. The open land market is a long-term stimulus factor for agricultural production.

Thus, in our opinion, it is possible to distinguish the following stages of the current institutional transformation of Ukrainian agricultural sector:

- first - 1991-1999;

- second - 2000-2008;

- third - 2008-2014;

- fourth - 2014-2019;

- fifth - since 2020.

Visually, the stages of the institutional transformation of the Ukrainian agricultural sector are presented in Figure 1 on the basis of statistical data on the dynamics of agricultural production in Ukraine.

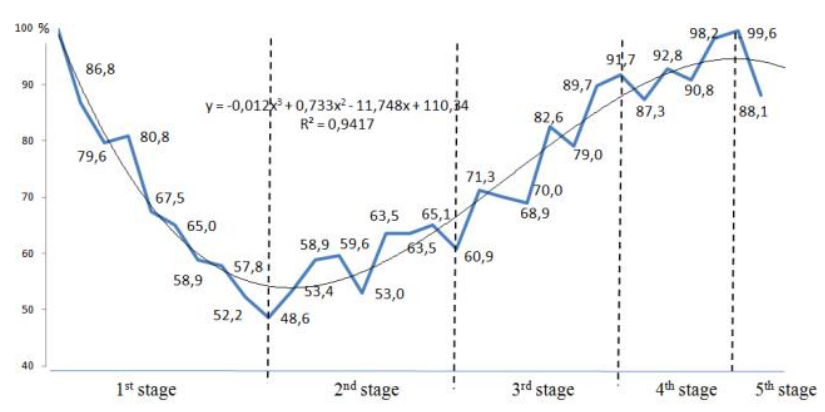

Fig.1: Indices of agricultural production of Ukraine (per cent to the 1990) [16] 
The proposed stages of phasing transformation of the agricultural sector of Ukraine are the author's vision of the processes and thus differ from previous works in literature.

\subsection{Sustainable Development of Agricultural Sector of Ukraine}

Estimates of social development from the standpoint of the national economy traditionally cover socioeconomic components and characteristics. At the same time, the ecological component is added to the classical duality of socio-economic development, since the ecological situation in the world and Ukraine in particular is significantly worsening. This is especially true for the national agricultural sector, which shows the low social protection of workers and people living in rural areas on the background of generally positive dynamics of economic growth. A polluting effect on the environment is caused in the process of agricultural production. On the other hand, the sector is suffering from the deterioration of the natural and climatic conditions. This implies the need to adhere to the concept of triune development - economic, social and ecological, which is called sustainable. At the same time, in our opinion, the institutional component should be added to this list.

Sustainable development of the agricultural sector is defined by us as development based on the balance and combination of such important determinants as economic, environmental, social, and institutional, as well as the interaction of these components on the basis of a systematic and synergistic approach. The economic component is to maintain a certain level of profitability. Ecological concerns preserving nature and its ability to recover. Social is to ensure a certain standard of living of the population today and in the future. Institutional component (in particular - institutional support) forms the institutional basis for sustainable development of the agricultural sector.

Regarding Ukraine, the situation as to sustainable development is not quite favorable. The most threatening are the following:

- Economic limitations;

- Social inequality;

- Ecological problems;

- Institutional imperfection.

Among the determinants of the sustainable development of the agricultural sector of Ukraine there is an imbalance with giving priority to the economic component while neglecting the environmental and social ones. This is partly due to the insufficient level of institutional determinant development.
Ukraine does not yet have the mechanisms to ensure sustainable development. This is also true because the process of introducing and implementing the concept of sustainable development, directly linked to technological structures, should facilitate their change (transition to a higher stage of development).

The process of sustainable development in Ukraine is hampered by such factors: the low level of competitiveness of the Ukrainian economy; structural distortions; extensive development of the agricultural sector on outdated technologies; inefficient and ineffective use of resources; careless attitude to the environment; low productivity and insufficient wages. As a consequence, there is limited social protection for the villagers. Such complexity makes it necessary to study the process of sustainable development from the standpoint of a systematic approach. It should be considered that the process itself dynamically changes the properties of the economic system and is non-linear. Thus, the transition to the concept of sustainable development requires, on the one hand, innovation and investment, on the other - the effective interaction between stakeholders.

The concept of agrarian transformations should have benchmarks - clearly defined institutional framework (institutional matrix) of sustainability. This will reduce random fluctuations in the number of agricultural producers and production volumes, prices for agricultural products, etc. Institutional changes are taking place under pressure from interested institutions, on the one hand, and disinterested ones, on the other. The present state of the agricultural sector of the Ukrainian economy will be defined as an unstable compromise caused by the current ratio and correlation of these forces. In an unstable institutional environment, conflicts between the institutions are also possible.

One of the components of successful market progress is perfection of institutional support for the agricultural environment. Today imperfect institutional system hinders the sustainable development of the agricultural sector.

Of course, equilibrium is possible when balancing the interests of all actors of the national economy, which is conditioned by a set of additional factors and conditions for sustainable development, such as information, innovation, technological, political and other factors. Additional restrictive factors of sustainable development in Ukraine and the agricultural sector in particular, is the impact of the complementary determinants. They are the following: fragmented institutional basis; the lack of political will to complete radical 
reform; the low information support of all components of agricultural development; the weak technical and technological base of agricultural development; the low organizational support for balancing other components as the basis for making effective management decisions.

Building an effective agricultural sector of the economy is related to a combination of factors of internal and external environment. The balance of these factors requires the removal of the incapacity of the existing economic mechanisms and incentives to attract efficient mechanism for the sector. The same important are the proportions of state and market regulation of social and economic processes of agrarian sphere. We must form a basis for revitalization of the agricultural business as the nucleus formation of modern economic forms that have come to replace individualized production. The goal of the reforms is to create a competitive agricultural sector of the national economy in the context of further institutional transformation of the agrarian matrix of market orientation on the basis of sustainable development concept.

Improvement of economic support mechanisms in implementation of sustainable development at the level of Ukrainian agricultural enterprises is proposed on the basis of balancing of processes of state regulation and market self-regulation. On the one hand, it is a set of components of public policy, government administration, and national programs of agricultural development. On the other hand, market self-regulation and free entrepreneurship as an important complement to the agricultural production are added here.

The necessary conceptual components of the national economy greening strategy, including the agriculture, are the following: environmental orientation of all economic actions; ecological regulation of agro-production projects and economic activities on the basis of standardized principles and requirements; environmental justification for the use of natural resources. It is important to direct economic activities to mitigate environmental pressures on environmental area, directly or indirectly involved in agro-industrial processes. The effective implementation of this mechanism will be modern management leverage - ecological management, environmental auditing, and ecological marketing as a system of effective tools for economic development within the permissible load on the environment.

Prospects for practical implementation of the national concept of sustainable development of the Ukrainian agricultural sector by environmental determinants should be related to the following directions: development of modern regulatory mechanisms at the level of optimal environmental management; interaction of ecological, economic and social constants of agricultural development; introduction of new forms and methods of agrarians revival and increase of efficiency of traditional technologies adapted to the Ukrainian agrarian system.

The introduction of the principle of optimal environmental management in agriculture is proposed to ensure the processes of use and processing of natural resources, the use and protection of natural objects, maintaining the productivity of natural complexes within agroecological landscapes of different levels of importance.

The significant factor is the social leverage of implementing the concept of sustainable development in the system of agrarian relations in Ukraine. It will generate new approaches to understanding the essence of rural areas not only as agro-industrial environment, but also as one of the areas of human relations and revival of the Ukrainian village. Agrarian policy and agrarian renewed culture should be considered as methodological tools to implement social deterministic approaches. In interaction they will reflect the multi-level set of relationships, decision making, management actions, and prospects for sustainable agro-ecological development on the basis of the required social development.

It is proposed to apply a multilevel approach to the system of harmonization of the determinants of sustainable development in the internal management of agricultural enterprises, regional, sectoral and national regulation, taking into account Ukraine's international commitments, European standards and the Resolution of U.N. "Transforming our world: the 2030 Agenda for Sustainable Development" [3].

At the level of agricultural entities, it is important to promote modern sustainable agricultural production, taking into account the need for environmental protection, diversification of production and manufacturing, and introduction of alternative farming systems. This should be facilitated by the widespread use of environmentally friendly methods, in particular organic production, and the use of biotechnology. Organic products are widespread in the world and in Ukraine, and their public awareness and appreciation are increasing.

Maximum self-sufficiency of regions in the food chain is promising, as localization of food production and consumption reduces food routes, saves on distribution and marketing, improves the environmental situation by reducing transportation, 
takes into account local taste preferences, promotes support for farmers [17]. Ukraine is one of those regions that have a high potential level of food selfsufficiency. It is necessary to develop local production of final food, to more actively introduce the signs of origin of food, to form a new culture of nutrition, or rather - to restore old, forgotten, displaced by multinational companies and national giants of the food industry.

Thus, the author's vision is that the implementation of sustainable development in agriculture and in the economy of Ukraine as a whole requires a systematic approach considering dynamic and non-linear nature of modern social development. Priority attention should be focused on the basic determinants of sustainable agricultural development: economic, social, ecological and institutional. The organizational, economic and technological components of sustainable development of the national agricultural sector must be improved on an innovative basis. At the same time, without the synergistic stakeholder engagement, achieving the desired result is problematic.

The authors believe that derived from the discussion the findings and results are generalizable.

\section{Scenario Forecasting}

Therefore, to ensure the efficiency of the agricultural management requires a set of favorable factors. On the one hand, the effectiveness and efficiency of the functioning of the agricultural system is undoubtedly influenced by its links with the external environment. Thus, the future of the sector is inevitably linked to overcoming the intersectoral disparity, forming partnerships with counterparties. This will ensure overall savings by reducing transaction costs, and will help to protect farmers' interests. On the other hand, informal and subjective factors occupy an important place. So new economic thinking and entrepreneurship of agrarians should be formed, and conditions for their adaptation to market economic requirements should be created.

The first factor component relates to the external environment - the institutional conditions for the functioning of the sector. The second is decisive in the formation of a new type of institutional agrarian matrix. The leverage of economic, social and ecological interests should positively influence the course of events.

Scenarios are options for long-term development that are determined by the degree of compliance of the agricultural system with the influence of factors. The research is based on the method of expert evaluations. The institutional approach also serves as a methodological basis for our scenarios method.

The scenario method is based on the identification of obstacles and deficiencies in the implementation of the desired direction of development.

The author's forecast for the further formation and development of the agricultural sector of Ukraine covers three scenarios: pessimistic, realistic, and optimistic.

The pessimistic scenario - the agricultural sector will remain unchanged. This scenario is not optimal from any position or attribute of assessment.

The realistic scenario is the gradual entry into the agricultural sector of Ukraine of capital from outside (of different origin), the purchase of land plots (after the moratorium has been lifted), the change of organizational and economic forms, the displacement of small producers, the increase in concentration and the level of monopolization with the gradual increase in agricultural commodity prices. This scenario is optimal from economic point of view, but not in terms of social or environmental performance. It will have a positive impact on the owners of agricultural enterprises, but will negatively affect consumers of agricultural products. It will contribute to reducing employment in the agricultural sector with increasing unemployment, further pollution of the environment and so on.

The optimistic scenario - the development of the agricultural sector based on multiculturalism, diversity of forms of business organization and balance of the interests of its members and contractors, legalization of internal capital (including earned abroad by Ukrainian villagers); attracting investment on an equal relationship with external (non-agricultural) structures and innovation in the agricultural sector in the conditions of favorable institutional environment. This scenario is determined by gradual capitalization of the agricultural sector, fewer side social negatives, a higher level of balance in terms of economic, social and environmental indicators that is more desirable from the standpoint of farmers and society. Therefore, efforts must be made to implement it.

However, the assessment of scenario is complicated by the nonlinear dynamics of the agricultural sector.

In general, our expert assessment and evaluations are based on previous author's research, but at the same time, they are probabilistic. Possible scenarios are only listed here. Future results will depend on the totality of measures taken at macro-, meso- and microeconomic levels. It also determines the task of further research in this area. 


\section{Conclusion}

The agricultural sector of Ukraine has gone through a difficult path of reform and transformation. The sector was characterized by a crisis phase, which was replaced by economic recovery. However, the sustainability of agrosphere development and the functioning of agribusiness have not yet been achieved. Since priority is given today to economic results, ecological and social components are far behind in the overall progress of sustainable agricultural development. As a consequence, the agricultural sector of Ukraine has a high level of environmental pollution and a low level of social support.

We consider this state of affairs to be the result of the phased development of the agricultural sector of Ukraine, which we divide into five institutional stages.

If we say that the further development of the agricultural sector should be regulated (at the level of external regulation or self-regulation), then in our opinion, the concept of sustainable development should be the basis for this.

The agricultural sector of Ukraine in the near future may develop under different scenarios, which we define as pessimistic, realistic, and optimistic.

The future will show how events will develop. The speed of change and the formation of effective market institutions will play an important role among the factors of further development. The concept of transformation, improvement of market institutions and corresponding favorable social, economic and ecological area of functioning of Ukrainian agricultural sector will ensure the formation of structures and relationships. This together guarantees the sustainable development of the sector taking into account the chosen vector of institutional changes.

\section{References:}

[1] Schumpeter, J. A. Capitalism, socialism and democracy. Virginia: Floyd. 2012.

[2] North, D. C. Institutions, Institutional Change and Economic Performance. Cambridge: Cambridge University Press. 1990.

[3] Transforming our world: the 2030 Agenda for Sustainable Development. $2015 . \quad$ United Nations, General Assembly. A/RES/70/1. https://www.un.org/ga/search/view_doc.asp?sy $\mathrm{mbol}=\mathrm{A} / 70 / \mathrm{L} .1 \&$ Lang=E.

[4] Lehman, H., Clark, E.A. \& Weise, S.F. Clarifying the definition of Sustainable agriculture. Journal of Agricultural and
Environmental Ethics. 1993. 6, pp. 127-143. https://doi.org/10.1007/BF01965480

[5] Appleby, M.C. Sustainable Agriculture is Humane, Humane Agriculture is Sustainable. Journal of Agricultural and Environmental Ethics. 2005, Vol. 18, pp. 293-303. https://doi.org/10.1007/s10806-005-1490-9

[6] Suci Paramitasari Syahlani, Anton Agus Setyawan, Mujtahidah Anggriani, Ummul Muzayyanah. Customer Loyalty Factors of Small Scale Farmers in Purchasing Poultry Feed. WSEAS Transactions on Business and Economics, ISSN / E-ISSN: 1109-9526 / 22242899, Volume 16, 2019, Art. \#43, pp. 379-392.

[7] Asrol Heriyanto. Structures of Revenue, Expenditure, and Welfare of Household Farmers in Kampar Regency, Riau Indonesia. WSEAS Transactions on Business and Economics, ISSN / E-ISSN: 1109-9526 / 22242899, Volume 16, 2019, Art. \#1, pp. 1-8.

[8] Borodina O. et al. Sustainable Agriculture, Food Security, and Socio-Economic Risks in Ukraine. In: Ermoliev Y., Makowski M., Marti K. (eds). Managing Safety of Heterogeneous Systems. Lecture Notes in Economics and Mathematical Systems. 2012, vol. 658, pp. 169187. Springer, Berlin, Heidelberg. https://doi.org/10.1007/978-3-642-22884-1_8

[9] Tetyana Zinchuk, Nataliia Kutsmus, Oleksandr Kovalchuk, Olga Charucka. Challenges of sustainable development of rural economy. Management Theory and Studies for Rural Business and Infrastructure Development. 2018, Vol. 40, No. 4, pp. 609-619. http://doi.org/10.15544/mts.2018.53.

[10] Oleksandr Shpykuliak, Olena Sakovska. Agricultural cooperation as an innovation for rural development. Baltic Journal of Economic Studies. 2020, Vol. 6, No. 3, pp. 183-189. https://doi.org/10.30525/2256-0742/2020-6-3183-189

[11] Onegina, V., Megits, N., Antoshchenkova, V., \& Boblovskyi, O. Outcome of capital investment on labor productivity in agriculture sector of Ukraine. Journal of Eastern European and Central Asian Research, 7(1), 2020. pp. 12-25. https://doi.org/10.15549/jeecar.v7i1.355

[12] Barua, Suborna, Understanding Coronanomics: The Economic Implications of the Coronavirus (COVID-19) Pandemic (April 1, 2020). SSRN: https://ssrn.com/abstract=3566477

or http://dx.doi.org/10.2139/ssrn.3566477

[13] Elleby, C., Domínguez, I.P., Adenauer, M. et al. Impacts of the COVID-19 Pandemic on the Global Agricultural Markets. Environ Resource 
Econ, 2020, 76, pp. 1067-1079. https://doi.org/10.1007/s10640-020-00473-6

[14] Farmers and agribusinesses at risk under COVID-19: What role for blended finance funds? Food and Agriculture Organization of the United Nations, July, 2020, 11 p. http://www.fao.org/3/ca9753en/CA9753EN.pdf

[15] The impact of COVID-19 on food security and nutrition: policy brief: Food and Agriculture Organization of the United Nations, June, 2020. 23

https://www.un.org/sites/un2.un.org/files/sg_po licy_brief_on_covid_impact_on_food_security. pdf

[16] State Statistics Service of Ukraine. Official web-site. http://www.ukrstat.gov.ua

[17] Pollan, M. In Defense of Food: An Eater's Manifesto. New York: Penguin Press. 2008.

\section{Author Contributions:}

Yurii Lopatynskyi was responsible for the conceptualization of ideas; formulation or evolution of overarching research goals, aims, and conclusion. Zoriana Kobelia has organized and executed the scenario forecasting.

Liubov Vodianka has implemented the methodological approach.

Iryna Antokhova has implemented the phasing transformation of the agricultural sector of Ukraine.

Andzhei Halytskyi carried out the Section of the sustainable development of agricultural sector of Ukraine.

\section{Creative Commons Attribution License 4.0 (Attribution 4.0 International , CC BY 4.0)}

This article is published under the terms of the Creative Commons Attribution License 4.0 https://creativecommons.org/licenses/by/4.0/deed.en US 